\title{
Any Theory Can Be Useful Theory, Even If It Gets On Our Nerves
}

\author{
Mark Schaller \\ University of British Columbia
}

\begin{abstract}
The science of social psychology would benefit from a renewed commitment to big brash theory. Jost and Kruglanski (this issue) suggest that social constructionist themes and attitudes may be useful in this regard. I elaborate further on the ways in which social constructionist theory can indeed inspire conceptual boldness but warn that constructionist approaches can also be conceptually constraining. Social psychology will benefit most if social psychologists emulate social constructionists' willingness to engage in "unnecessary" speculation but rebel against constructionists' unwillingness to seek universally applicable theories. Social constructionism challenges us to confront big questions, and the science of social psychology will best be spurred forward if we respond to that challenge by seeking big bold answers.
\end{abstract}

I was at a dinner not long ago with some experimental social psychologists, and we got to talking about a book that a number of us had read, in which the author seeks to identify the causal agents in the eventual fates of human societies. We all spoke highly of the author's ambitious attempt to apply a causal-modeling type of analysis to the study of human history. I mentioned that I had taken part recently in another discussion of the same book with some colleagues from other academic disciplines, and I noted that one of them objected strenuously to its linear, predictive approach. To a bunch of social psychologists, this seemed an odd thing to object to, and one of my dinner mates asked for elaboration about the basis of the objection. I did not want to attempt a tediously lengthy answer, and so I took a stab at a glib sort of shorthand instead. "She's a political theorist,' I said. My glib shorthand did not work; my dinner companions squinted and frowned, and someone wondered aloud why a political scientist might object. I tried to clarify. "She's not just a political scientist," I said, "She's a political theorist." It still was not working, so I tried again: "She's a social constructionist." That did the trick. There were snorts and chortles all around as eyes rolled skyward, and the conversation moved on.

It felt momentarily good, of course, to utter a line that rang the room with laughter, and to share in the implicit dismissal of an academic outgroup that contentiously disputes the accustomed epistemic style of experimental social psychology. Nevertheless, this was

The preparation of this article was supported by a grant from the Social Sciences and Humanities Research Council of Canada. Thanks also to Chris Crandall and Doug Kenrick for helpful comments on an earlier draft.

Reprint requests should be sent to Mark Schaller, Department of Psychology, University of British Columbia, 2136 West Mall, VancouverBC V6T 1Z4,Canada.E-mail: schaller@cortex.psych.ubc.ca not a particularly proud moment. I was trafficking in stereotypes, and I knew it.

Among many social psychologists, the term social constructionist stimulates a stereotype personified, I think, by vague images of erudite-but-shrill antiscientific cranks. This makes it all too easy to treat social constructionism with either immediate rejection or indifferent ignorance. That's unfortunate. The stereotype surely does a disservice to the varied set of ideas and methods associated with social constructionism.

The article by Jost and Kruglanski (this issue) should help dissolve this stereotype, so that social constructionism will no longer be a stimulus merely for rolling eyes and cheap laughs. If we attend carefully to our shared academic history and intellectual agenda, we can draw on social constructionist themes for inspiration. In addition, if we respond boldly and open-mindedly to social constructionist critiques, we may position ourselves to discover ever-more interesting and important truths about psychology and the social world. Some social constructionist ideas can be threatening, yes, and some have been expressed in ways that are just plain irritating. Nonetheless, our science-now more than ever-would benefit from an "anything goes" approach to theory and methods (Feyerabend, 1975); so social constructionism may be useful in spurring scientific progress.

\section{The Boldness Deficit in Social Psychology}

Jost and Kruglanski remind us again that there are a lot of folks-including many social psychologists themselves-who perceive that the contemporary social psychological literature suffers from something of a deficit in conceptual boldness. We have become 
so concerned with the avoidance of being wrong, that we are disinclined to try to be ambitiously right. Much has been written of this boldness deficit, and the possible psychological and sociological causes of institutionalized risk aversion (e.g., Crandall \& Schaller, in press; Higgins, 1992; Kruglanski, 2001). Jost and Kruglanski usefully draw our attention to the historical context of this trend. They suggest that social constructionism played a role in precipitating this risk-averse attitude, and that it might now help provide a cure.

\section{First Things First}

If social constructionism is to serve as a stimulating cure for conceptual timidity, it will require a less defensive response from social psychologists than it received in the so-called crisis years of the 1970s. Jost and Kruglanski provide a reader-friendly road map and summarize some of the useful highlights of social constructionist thought. For those of us who were tempted to dismiss social constructionism as airy postmodern hogwash, Jost and Kruglanski's article should inspire more respect for the intellectual richness of the constructionist enterprise. For those of us who worried that social constructionism was merely an excuse for cranky anti-science polemics, their article should be reassuring about our intellectual kinship.

Social constructionism is not such a bogeyman after all. In his introduction to a recent special issue of Theory and Psychology, Stam (2001) writes that the constructionist movement seems to have "left the gritty, exciting and perhaps even dangerous downtown streets of academia and has settled comfortably in its suburbs ... the term 'social constructionism' no longer leads people to draw their blinds or call out the dogs" ( $p$. 291). The rapprochement that Jost and Kruglanski advocate seems already to be occurring within psychology more broadly, and it would be good if more experimental social psychologists got in on the conversation. If we do so, we will discover that social construction is more sophisticated than the 1970s-style crankiness that many of us learned to ignore-and richer even than suggested by Jost and Kruglanski. Stam reminds us forcefully that there is no single social constructionist position, nor even a single social constructionism "movement." Edwards (1997) and Edley (2001), among others, provide useful perspectives on the diversity of social constructionist theory and thought.

In short, there are a lot of different themes and ideas in the social constructionist literature. Some of these themes are sure to get on our nerves, while some-such as the study of communication and the content of socially shared beliefs-will seem more immediately approachable. Whether fierce or friendly, any social constructionist idea will be useful if it compels us to think in new and different ways. Nisbett (1990), among others, noted that scientific creativity is most likely to be fostered by reading outside, rather than within, one's own scientific discipline. A little social constructionism on the bedside table might therefore be just the tonic to help cure the boldness blues.

\section{Let's Be Brash: The Case for Unnecessary Speculation}

No matter what we think about the substance of social constructionist thought, we should appreciate the style. Jost and Kruglanski assert that, in general, social constructionists feel less constrained by empirical data than experimental social psychologists, and as a consequence feel freer to speculate broadly about the way the world works. It's a style worth imitating.

The social-psychological retreat from unconstrained speculation is evident in the way that social psychologists reacted to social constructionist writings in the 1970s. Jost and Kruglanski quote Gergen's (1977) remark that "behavioral data serve much as blank slates that permit the investigator to inscribe the theoretical message of his or her choosing" (p. 168) and argue that social psychologists read this and similar statements as signs of institutional weakness - as criticisms to be addressed by both beefing up our data, and slimming down the theoretical stories that we wrap around those data. One consequence is salutary: Our empirical studies are better than ever at distinguishing objective fact from theoretical fancy. Another consequence, however, is very problematic: Too many of our published articles now have overly fat empirical midsections sheathed in insubstantial conceptual skins.

However, Gergen's (1977) rhetorical intent notwithstanding, that quoted remark can also be read in a more positive way - as an invitation to tell bolder and more interesting theoretical tales. If our data allow us some choice - any choice at all - in theoretical message mongering, then by all means, we should take advantage of that option.

Social psychologists tend to be unusually fussy when data and theory are juxtaposed. As consumers of empirical results, we are both demanding and oddly ascetic: We want to be provided with a sufficient amount of theory-just enough to explain the data-and we do not want anything extra. We often reject as "unnecessary" any additional layers of theoretical speculation that attempt to locate psychological data within bigger, bolder conceptual frameworks. There are surely many reasons for our discomfort with theoretical luxury. We probably buy too strongly into the principle of parsimony, even though the appeal of parsimony lies primarily in psychological solace and not in scientific logic (Schaller, Rosell, \& 
Asp, 1998; Sober, 1990). In addition, we are probably too easily tempted to apply our everyday desires for attributional certainty to the scientific enterprise (Conway \& Schaller, 2002), even though this enterprise requires the constant introduction of unjustified speculation in order to keep moving forward. In any case, an intolerance for "unnecessary" theorizing is ultimately bad for scientific progress.

Therefore, we would benefit from a little less circumspection, a bit more brashness. Once we have made good on the demand to provide some satisfactory explanation for empirical results, additional layers of theory can and should be thrown in for free. We are not selling our conceptual stories to unsuspecting simpletons. The readers of our journals are well-educated, skeptical shoppers; we should trust them to be both willing and able to separate empirical fact from theoretical speculation. We should worry less about whether a chunk of theory is absolutely necessary to explain some puny piece of data; we should think more about whether that conceptual chunk might actually describe some aspect of human nature. We should encourage ourselves and our colleagues to exploit our slates of experimental data, to inscribe them with as much big bold theorizing as we coherently can.

It is this sense-the willingness to speculate grandly beyond the data given - that we would do well to emulate the intellectually brash approach of our cousins the social constructionists. If we do, our science will be more exciting, progressive, and fun.

\section{Let's Be Even Brasher: The Case for Universalism}

However, we should be careful not to emulate all elements of social constructionist thinking; some aspects of social constructionism are not so brash at all. Social constructionism might encourage a style of immodest thinking, but it does not necessarily encourage "grand theorizing" about things of substance-at least not in the sense that matters most in the realm of social psychology.

Social psychology is not sociology, anthropology, or history; it is psychology. The grandest theories in psychology are those that describe general principles of cognition and behavior, principles that apply to the broadest range of the human population. The intellectual agenda of the psychological sciences is not merely to describe the thoughts and behaviors of populations constrained by time and space (folks in other disciplines are happy to do that work) but instead to discover universal truths about human nature. One message of social constructionism is that this universalist goal is unattainable. Here is where the substance of social constructionism is anything but brash and bold, but is conceptually constraining instead; hubris beats humility as the best response. If we stop trying to discover universal truths about human nature, then we are no longer doing our job.

No psychological theory can be considered grand if it applies merely to some small cultural population at some limited moment in time. Work in cross-cultural psychology provides a case in point. As Jost and Kruglanski indicate, the study of cross-cultural differences in social cognition offers an excellent example of social constructionist themes operating within the social psychological literature. These cross-cultural inquiries are absolutely necessary, and the implications are both interesting and important. However, the documentation of cultural differences does not lend itself easily to the discovery of general principles. If anything, the opposite is true: The more that evidence piles up attesting to the influence that culture has on cognition, the more reluctant psychologists may be to adopt a universalist perspective (Heine, Lehman, Markus, \& Kitayama, 1999; Nisbett, Peng, Choi, \& Norenzayan, 2001).

The challenge posed by cross-cultural psychologyand by social constructionism - is not a whole lot different from the challenge posed by personality psychology. We already know that individuals differ, and that these differences exert important influences on cognition and behavior. Some of these individual differences are scattered randomly across social geographies, and somethose that we call "cultural"-are clumped and clustered according to spatial, temporal, or demographic categories. The fact that there are individual differences does not prevent us from seeking to discover the universal biological, cognitive, and developmental processes that underlie the origin and operation of those differences. Similarly, the fact that there are cultural differences challenges us to contend to with a parallel set of questions about the origin and operation of those cultural differences. If we are willing to boldly meet this challenge, we can apply distinctly social-psychological tools to questions that are raised, but not answered, by social constructionist assumptions.

Jost and Kruglanski identify usefully one important question that cries out for ambitious inquiry: Through what universally human processes does culture-any culture-influence cognition and behavior?

In addition, the social constructionist emphasis on culture brings into sharper focus another set of questions that demand, if anything, even more ambitious theorizing about human nature. How do cultures arise in the first place? Why do these particular cultures arise, and not others? And why do these cultures evolve and change in the specific ways that they do?

These are huge questions, and hugely interesting as well. As social psychologists, we usually set our sights on somewhat smaller game, and so are not accustomed to addressing questions as ambitious as these. But we 
can. If culture is, as Sperber (1990) suggested, "the precipitate of cognition and communication," (p. 42) then social psychologists are uniquely poised to provide meaningful answers. A number of general social-psychological principles pertaining to cognition, motivation, and interpersonal influence have irresistible implications for predicting the origins and evolution of belief systems, behavior norms, and other defining features of culture (Latané, 1996; Norenzayan \& Atran, in press; Richter \& Kruglanski, in press; Schaller, Conway, \& Tanchuk, 2002; Solomon, Greenberg, Schimel, Arndt, \& Pyszczynski, in press).

Some of the most promising theoretical tools for addressing these questions about culture are provided by an ambitious metatheoretical approach that Jost and Kruglanski allude to only briefly: evolutionary psychology. Like social constructionism, evolutionary psychology (and the broader sociobiological perspective from which it emerged) can get on the nerves of social scientists. However, in most other respects, evolutionary psychology diverges starkly from the epistemic position of social constructionism. Theories within evolutionary psychology are grandly universalist; the conclusions they imply about human nature are the sort of sweeping statements that make many social constructionists wince. And yet, when applied cleverly and rigorously, these theories yield provocative predictions about the contents of cultural beliefs and norms and can even help to explain the emergence of cultural variability across different pockets of the human population (Kenrick, Li, \& Butner, in press; Kenrick, Maner, Butner, Li, Becker, \& Schaller, in press; Krebs \& Janicki, in press). This sophisticated style of evolutionary theorizing is a far cry from the stereotype of sociobiology that Jost and Kruglanski express dissatisfaction with. It is not reductionist; it is integrative. It does not dismiss history and culture from consideration but rather applies a particular sort of historical analysis to fundamental questions about culture and its contents. It is exactly the sort of boldly ambitious multilevel theorizing that is necessary to address the big questions about cognition and culture that social constructionism can inspire us to ask.

Clearly, one does not have to buy into all, or even any, elements of social constructionist epistemology to be inspired to address big questions about culture that emerge from social constructionist writings. We do not even absolutely need social constructionism to stimulate those questions; there are plenty of other sources of inspiration that we can tap into as well. But so what? Anything that stimulates us to think bigger is a good thing.

\section{Envoi}

In my experience, experimental social psychologists are a pretty fun-loving bunch, and so we may not be able to resist entirely the temptation to chuckle occasionally at the excesses of social constructionist rhetoric. However, we are also a pragmatic people who-when we allow ourselves — recognize the utility of interesting ideas. Therefore, we should take social constructionist themes more seriously. Social constructionism provides a model for bold speculative theorizing that breaks free of empirical constraints. It is a style that gets on some scientists' nerves, but if we care about the future health of our science, it is a style worth adopting as our own. Not all elements of social constructionism are so bold, however; a lot of social constructionist writings assert a state of social affairs that implies strict limits to the alleged universality of human nature. This assertion too can get on some social psychologists' nerves, and it could have an unhealthy effect on our science if we react to it by retreating from our universalist tendencies. If, however, we respond to this challenge as we should-with renewed brashness of our own - then we can be inspired to vigorously address big questions that formerly lay outside the scope of social psychological inquiry. In doing so, we may discover fresh truths about human cognition, human culture, and human nature.

\section{References}

Conway, L. G., III, \& Schaller, M. (2002). On the verifiability of evolutionary psychological theories: An analysis of the psychology of scientific persuasion. Personality and Social Psychology Review, 6, 152-166.

Crandall, C. S., \& Schaller, M. (in press). Scientists and science: How individual goals shape collective norms. In M. Schaller \& C. S. Crandall (Eds.), The psychological foundations of culture. Mahwah, NJ: Lawrence Erlbaum Associates, Inc.

Edley, N. (2001). Unraveling social constructionism. Theory and Psychology, 11, 433-441.

Edwards, D. (1997). Discourse and cognition. London: Sage.

Feyerabend, P. (1975). Against method. London: New Left.

Gergen, K. J. (1977). The social construction of self-knowledge. In T. Mischel (Ed.), The self: Psychological and philosophical issues (pp. 139-169). New York: Academic.

Heine, S. J., Lehman, D. R., Markus, H. R., \& Kitayama, S. (1999). Is there a universal need for positive self-regard? Psychological Review, 106, 766-794.

Higgins, E. T. (1992). Increasingly complex but less interesting articles: Scientific progress or regulatory problem? Personality and Social Psychology Bulletin, 18, 489-492.

Kenrick, D. T., Li, N. P., \& Butner, J. (in press). Dynamical evolutionary psychology: Individual decision-rules and emergent social norms. Psychological Review.

Kenrick, D. T., Maner, J., Butner, J., Li, N. P., Becker, D. V. \& Schaller, M. (in press). Dynamical evolutionary psychology: Mapping the domains of the new interactionist paradigm. Personality and Social Psychology Review.

Krebs, D., \& Janicki, M. (in press). Biological foundations of moral norms. In M. Schaller \& C. S. Crandall (Eds.), The psychological foundations of culture. Mahwah, NJ: Lawerence Erlbaum Associates, Inc.

Kruglanski, A. W. (2001). That "vision thing": The state of theory in social and personality psychology at the edge of the new millennium. Journal of Personality and Social Psychology, 80, 871-875. 
Latané, B. (1996). Dynamic social impact: The creation of culture by communication. Journal of Communication, 46(4), 13-25.

Nisbett, R. E. (1990). The anticreativity letters: Advice from a senior tempter to a junior tempter. American Psychologist, 45, 1078-1082.

Nisbett, R. E., Peng, K., Choi, I., \& Norenzayan, A. (2001). Culture and systems of thought: Holistic versus analytic cognition. Psychological Review, 108, 291-310.

Norenzayan, A., \& Atran, S. (in press). Cognitive and emotional processes in the cultural transmission of natural and nonnatural beliefs. In M. Schaller \& C. S. Crandall (Eds.), The psychological foundations of culture. Mahwah, NJ: Lawrence Erlbaum Associates, Inc.

Richter, L., \& Kruglanski, A. W. (in press). Motivated close mindedness and the emergence of culture. In M. Schaller \& C. S. Crandall (Eds.), The psychological foundations of culture. Mahwah, NJ: Lawrence Erlbaum Associates, Inc.

Schaller, M., Conway, L. G., III, \& Tanchuk, T. L. (2002). Selective pressures on the once and future contents of ethnic stereotypes: Effects of the communicability of traits. Journal of Personality and Social Psychology, 8.
Schaller, M., Rosell, M. C., \& Asp, C. H. (1998). Parsimony and pluralism in the psychological study of intergroup processes. In C. Sedikides, J. Schopler, \& C. Insko, (Eds.), Intergroup cognition and intergroup behavior (pp. 3-25). Mahwah, NJ: Lawrence Erlbaum Associates, Inc.

Sober, E. (1990). Let's razor Ockham's razor. In D. Knowles (Ed.), Explanation and its limits (pp. 73-93). Cambridge, England: Cambridge University Press.

Solomon, S., Greenberg, J., Schimel, J., Arndt, J., \& Pyszczynski, T. (in press). Human awareness of mortality and the evolution of culture. In M. Schaller \& C. S. Crandall (Eds.), The psychological foundations of culture. Mahwah, NJ: Lawrence Erlbaum Associates, Inc.

Sperber, D. (1990). The epidemiology of beliefs. In C. Fraser \& G. Gaskell (Eds.), The social psychological study of widespread beliefs (pp. 25-44). Oxford, England: Clarendon.

Stam, H. J. (2001). Introduction: Social constructionism and its critics. Theory and Psychology, 11, 291-296. 